\title{
China's Accession to the WTO: Timing is Everything
}

\author{
Terrie L. Walmsley \\ and \\ Thomas W. Hertel \\ Center for Global Trade Analysis \\ Purdue University ${ }^{1}$
}

September 2000

${ }^{1}$ Center of Global Trade Analysis, 1145 Krannert Building, Purdue University, West Lafayette, IN 47907-1145, USA. Walmsley is a post-doctoral research fellow at Purdue University. Email: walmsley@agecon.purdue.edu. Hertel is a professor at Purdue University. Email: hertel@agecon.purdue.edu. 


\title{
China's Accession to the WTO: Timing is Everything
}

Terrie L. Walmsley and Thomas W. Hertel

\begin{abstract}
Since China's application in 1987 to resume its status in the Generalized Agreement on Trade and Tariffs (GATT)/World Trade Organization (WTO) there has been a great deal of debate over the timing of China's accession. Although most of the issues relating to the timing of China's trade liberalization have been resolved, the abolition of restrictions on Chinese textiles and clothing may still be subject to delay if the United States and Europe choose to implement the safeguards contained in the their bilateral accession agreements with China as well as in the original Agreement on Textiles and Clothing (ATC).

In this paper, the effects of alternative target dates for the elimination of restrictions on textiles quotas are examined. Since this issue revolves fundamentally around the question of timing, it is most appropriately addressed in a dynamic model. In this study we use the Dynamic GTAP model. This is applied to a 19-region by 22-commodity aggregation of the GTAP database, supplemented with foreign income data.

The paper finds that timing is indeed an important determinant of the profile of structural adjustment required in China and the rest of the world. In light of their interest in delayed implementation the ATC, it is interesting to note that our results suggest slower elimination of these quotas is detrimental to national welfare in North America and Europe.
\end{abstract}




\section{Introduction}

In 1986, China notified GATT/WTO members of its wish to resume membership in that organization. China's application to join the WTO has aroused a number of concerns from both developing and developed member nations. Some of the issues raised have included how China's growth and accession will affect the world food markets (Anderson, Dimaranan, Hertel and Martin, 1997); whether China's accession will further increase the U.S. trade deficit (USITC, 1999); whether increased competition will result in lower real wages for skilled and unskilled workers (Scott, 1999); and how increased competition will affect the development prospects of other nations in South Asia who compete in similar markets to China.

China's bid for WTO accession has involved negotiation of individual agreements with key WTO members. Upon accession these bilateral agreements will then be extended to all WTO members. This long process of negotiation began in 1987. In November 1999, an agreement was reached between China and the United States and in May 2000 a similar agreement was reached between China and the European Union. These agreements have gone a long way towards removed the remaining obstacles to China's membership in the WTO.

The main concern of WTO member states has been to secure greater access to the growing Chinese market. The issues addressed during these negotiations provide for further market access for foreign companies and foreign investment, the reduction of tariffs and the implementation of bindings, elimination of quantitative restrictions, and the participation of China in other multilateral agreements relating to information technology, telecommunications and financial services (USITC, 1999). In this paper, only the quantitative effects of tariff reductions and ATC implementation are examined ${ }^{1}$.

An important issue in the negotiations between China and the other member states has been the timing of China's accession, including: a) when China should join; b) whether China should be treated as a developed or a developing economy - hence dictating the timetable for tariff cuts; and c) when quotas on textiles and wearing apparel should be abolished by North America and Europe. Under the Uruguay Round (UR) agreement, developing countries are permitted a longer period of time during which to implement their agreements. Many developed countries have argued that the large size of the Chinese market justifies its being treated as a developed economy and this is reflected in the final agreements with the United States and the European Union.

As China currently enjoys normal trading relations (NTR, previously MFN) status, WTO members are not required to further reduce their tariffs on Chinese goods. However, WTO membership would ensure China that these bound tariffs could not be increased in the future. In the base case scenario used in this paper, it is assumed that China would continue to enjoy NTR status even if it were not permitted to join the WTO. An important alternative scenario, where China loses its NTR status, could have been a clear possibility. The Chinese

\footnotetext{
1 A qualitative assessment of the possible effects, on investment and trade, of these commitments undertaken in the accession agreement is provided in USITC (1999).
} 
government was obviously concerned about this alternative scenario, but we do not explore it here.

China is not a party to the Uruguay Round's ATC agreement. Upon accession to the WTO China will also become eligible for the benefits obtained under this agreement, in particular the elimination of quotas on textiles and wearing apparel imported by North America and Europe from China. Elimination of these quotas, is likely to have a significant impact on the quota-constrained North American and European markets, as well as on the other developing economies which compete with China in these markets. This has led to concern by ATC importers, as well as competitor countries, about the effect of this on their own economies. Yang (1996) has shown that the elimination of the quotas on textiles and clothing accounts for a significant proportion of the welfare gains made by China and the United States from China's accession to the WTO, but it also gives rise to substantial sector adjustments.

In the agreement between the United States and China signed in November, 1999, China agreed to safeguards permitting a delay in the abolition of selected textile and apparel quotas until the end of 2008 (Gershman, 1999). The Uruguay Round Agreement on Textiles and Clothing also provides for safeguards that might allow the United States and Europe to delay abolition of some quotas until 2008 or 2012 at the latest. The effects of a delay in the removal of all textile and apparel import quotas on Chinese exports until 2010 is examined in this paper. While there is also the distinct possibility of North America and Europe frustrating implementation of this agreement on imports of textiles and wearing apparel from all sources, this is not considered in this paper.

China's WTO accession therefore involves both increasing access to Chinese markets through the reduction of trade barriers, as well as the removal of quotas on textiles by North America and Europe. Taiwan's liberalization is also included in this analysis as it is expected that once China's accession has been agreed upon, Taiwan's will automatically follow. While both the trade liberalization of China and Taiwan are included, the results focus on the effects of this liberalization on China.

A number of studies (Yang, 1996, Wang, 1997a and 1997b, USITC, 1999, Martin et al., 1999, Fan and Zheng, 2000, Ianchovichina et al., 2000, Yang and Tyers, 2000, Lejour, 2000, Zhai and Li, 2000) have been undertaken to examine the effects of China's accession to the WTO. In general, the results show that world trade increases substantially as a result of China's accession. The main winners from China's accession are China and Taiwan themselves. Wang (1997a) finds that North America and many of the other developed nations also gain as a result of increased exports, particularly of agricultural products. The removal of quotas under the ATC agreement appears to be a significant contributor to the benefits accruing to North America and China. Yang (1996) used the static GTAP model to examine the effects of differential timing of the accession. He concluded that there was little difference between whether China was treated as a developed or developing country for the purposes of accession. However, since this analysis was not conducted using a dynamic model, the differences in timing could not be implemented explicitly, thus making it difficult to distinguish between the alternative accession scenarios. In addition Yang (1996) did not examine the impact of a delay in the elimination of quotas under the ATC. 
In this paper the Dynamic GTAP model (Ianchovichina and McDougall, 1999) is used to more carefully examine the effects of timing on China and Taiwan's accession. The dynamic nature of the model makes it ideal for analyzing the effects of alternative timing scenarios. The effects of China's accession are examined over the period 1995 to 2020. This period is divided into a number of sub-periods, allowing the shocks to tariffs and to the quotas to be implemented in stages. In addition, the incorporation of international capital mobility in Dynamic-GTAP allows us to examine the effect of China's accession on foreign investment and the accumulation of capital.

Two policy scenarios are considered. The first assumes that China and Taiwan are treated as developed countries and therefore tariffs are reduced over a period of 5 years. In this case, the ATC agreement is assumed to be implemented by 2005 . In the second scenario, China and Taiwan are again treated as developed countries, however North America and Europe do not completely remove the quotas on textiles and wearing apparel from these regions until 2010.

The results confirm the finding of earlier studies that China and Taiwan are expected to gain the most from China's accession to the WTO. These gains are greatest when the quotas are removed quickly. North America and Europe also gain, and their gains are greatest when the Agreement on Textiles and Clothing is fully implemented by 2005. This result, suggests that the political debate over the delayed implementation of the ATC with respect to China is inconsistent with North America's national interests. Accordingly we also explore the sectoral adjustment required of the textile and apparel sectors in the ATC importer countries. Here, the benefits of delayed implementation are more apparent. In addition, we consider the impact on developing countries that compete with China in the wearing apparel and manufacturing markets. These competitors suffer as a result of increased competition when China joins the WTO. The delayed implementation of the ATC agreement for China does little to improve this situation, from the perspective of the developing countries.

The paper is divided into six sections. Section 2 provides an overview of some key facts about China's role in the World economy. Section 3 briefly reviews the model and data used to examine the effects of China's accession. In section 4 the base case scenario and policy simulations undertaken in this paper are outlined. Then in sections 5 and 6 the results are examined. Section 5 concentrates on the macro-economic results, while section 6 examines the sectoral effects of China's accession focusing specifically on wearing apparel. Section 7 offers conclusions.

\section{China And The World Economy}

Since the late 1970's the Chinese economy has undergone rapid changes. China's GDP has grown at a phenomenal rate. Between 1978 and 1995, per capita growth in real GDP averaged 6.04 percent (Maddison, 1998). In 1995 growth in real GDP exceeded 10 percent, and according to World Bank forecasts, (Global Economic Prospects Data Base, 1999) high growth rates are expected to continue to at least 2007.

Rapid growth has been fueled by a number of economic reforms undertaken by China since the early 1980's, including the reduction of tariff and non-tariff barriers, and the opening up of Chinese markets to foreign investment. Between 1992 and 1998, tariffs were 
reduced from an average of 42 percent to 17 percent (Fan and Zheng, 2000). These reforms have had a profound effect on trade. Exports and imports have been growing at an average rate of 22 percent per year since 1972 (Gelhar, 1998). This contrasts with the previous decade of the 60's when growth averaged only 10 percent per year.

This rapid growth has been accompanied by structural changes as the Chinese economy has shifted away from agriculture and into labor intensive manufactures such as wearing apparel and toys. In 1952, agriculture accounted for approximately 58 percent of GDP, but by 1995 this figure had dropped to just over 23 percent. Likewise manufactures has risen from 8.1 percent of GDP to 41 percent over the same period (Maddison, 1998). However, competition in the market for labor-intensive manufacturing has increased dramatically in recent years with the shift of other economies, notably South Asia, towards export-oriented strategies and production of labor-intensive commodities.

The rapid growth in China has also attracted a great deal of foreign direct investment (FEI). As can be seen from Figure 1, FDI sky-rocketed in the early 1990's. By 1994, China accounted for 20 percent of all FDI in developing countries (Garbaccio, 1995). FDI continued to grow until 1997 when it leveled off. Figure 1 also reports the broader - and more volatile - foreign investment figures for China. These include portfolio investment. Here it is clear that China fell out of favor in 1998, under the shadow of the East Asian Crisis.

In its most recent survey of China's economy, The Economist explores some of the reasons behind the slowdown in FDI in China. In many cases investor's high hopes for this market have been slow to materialize, with the absence of a rules-based economy making it difficult for outsiders to operate effectively in China. Informal relationships and corruption still hinder many business transactions by foreigners. In addition, inefficient state enterprises still dominate many key sectors of the economy. Quantitative analysis of these institutional problems is beyond the scope of this paper. However, we do explore the implications of WTO accession for market rates of return to investment in China. We find that accession can play an important role in enhancing China's attractiveness as a destination for foreign investment. The next section outlines the dynamic model which we use in our analysis. It places international mobility of capital at the forefront, thereby providing a useful vehicle for exploring the impact of China's WTO accession on foreign investment and economic growth in China.

\section{The Model}

The Dynamic GTAP model (GTAP-Dyn) developed by Ianchovichina and McDougall (1999) is used to analyze the effects of China's accession. GTAP-Dyn is a recursive-dynamic extension of the standard GTAP model (Hertel, 1997) which is a multiregion applied general equilibrium model. The dynamic model preserves all the features of standard GTAP, while enhancing the investment theory to incorporate international capital mobility and ownership.

The model is applied to a 19-region by 22-sector aggregation of the version 4 GTAP data base (McDougall et al., 1998). A list of these regions and sectors is provided in the Appendix, Table A.1. The GTAP data base is supplemented with foreign income data from 
the IMF Balances of Payments statistics in order to track international capital mobility and foreign wealth.

In the remainder of this section some of the features of the dynamic GTAP model are discussed. Sub-section 1, outlines the investment theory of the dynamic GTAP model and sub-section 2, illustrates how foreign ownership of capital has been incorporated into the model.

\subsection{Investment Theory}

The dynamic GTAP model uses a disequilibrium approach for modeling international capital mobility. A disequilibrium approach is necessary in order to reconcile the theory of investment with observed reality. Economic theory suggests that savings will be allocated across regions to those investments with the highest rate of return. With perfect capital mobility, rates of return must be equalized across regions. However, we do not observe equal returns at any given point in time. Therefore, in GTAP-Dyn, perfect capital mobility occurs only in the very long run. Investment is determined by the gradual movement of rates of return to equality across regions. This is the first use of the disequilibrium approach.

A corollary of the capital mobility theory is that if rates of return in a particular country are very low, investment will fall and vice versa. Implementation of this theory however leads to a dilemma. In many cases actual investment, as reported in the national statistics, does not correspond to that predicted by this theory. For example, low observed rates of return are found to co-exist with high rates of investment in some countries. Such discrepancies can be rectified in one of two ways: firstly, the data can be altered so that theory and data are consistent; or alternatively, the theory can be modified to more accurately reflect how the world works. In the dynamic GTAP model the latter method has been used. This has been achieved by incorporating errors in expectations about the actual rate of return. Thus investment is the result of the gradual movement of expected rates of return to equality across regions, but the expected rate of return may differ from the actual rate of return due to errors in expectations. This is the second use of the disequilibrium approach.

Determination of investment in the dynamic GTAP model may be illustrated with the help of Figure 2, taken from Ianchovichina and McDougall (1999). The two curves in Figure 2 show the expected and actual rate of return schedules. The expected rate of return schedule depicts the relationship between the expected rate of return $\left(r_{E}\right)$ and capital stock $(\mathrm{K})$, while the actual rate of return schedule shows the relationship between the actual rate of return $\left(r_{A}\right)$ and capital stock $(\mathrm{K})$. These curves are downward sloping reflecting the belief that, as capital stocks increase, rates of return will fall, ceteris paribus. The difference between these two schedules represents the errors in expectations (i.e. the difference between observed data and the postulated theory). In any given year, there is a temporary equilibrium, global rate of return, $r_{T}$, that ensures that global savings equal investment; this is depicted by the horizontal bar in Figure 2.

Investment in a particular year is determined by three mechanisms. The first is the desire to eliminate errors in expectations, which causes the expected rate of return to gradually move towards the actual rate of return. This involves the movement of the expected rate of return schedule towards the actual rate of return schedule (arrow 1 in Figure

2 ). In the case of China, the expected rate of return must rise to match the higher actual rates 
of return. Secondly gradual equalization across regions of rates of return requires the movement of the expected rate of return towards the temporary equilibrium $\left(\mathrm{r}_{\mathrm{T}}\right)$ (labeled 2 in Figure 2). With higher expected rates of return (as experienced in China) investment and capital stocks increase as the expected rate of return moves towards $\mathrm{r}_{\mathrm{T}}$. The third mechanism is the equalization of the growth rates of capital over time, with all three rates of return converging on a long-run equilibrium rate of return, $r^{*}$.

\subsection{Ownership}

With the incorporation of international capital mobility it becomes necessary, for purposes of examining the welfare effects of China's accession, to take account of foreign capital ownership. In the dynamic GTAP model, regional capital is owned by both domestic households and by foreign households via a global trust. The saving of each regional household is then allocated either to domestic investment or to foreign investment. This allocation assumes that the shares of domestic and foreign investments are held constant, subject to the adding-up constraints required to ensure regional saving and investment constraints. This is consistent with empirical evidence that investors tend to invest first in their home economies and then abroad.

Explicit modeling of the ownership of regional investment in China allows the accumulation of China's wealth by foreigners to be determined. In addition China's ownership of domestic and foreign assets can also be tracked. Income accruing from the ownership of these foreign and domestic assets can then be appropriately incorporated into total regional income, and hence welfare for both China and the rest of the world.

\section{The Base Case and the Policy Scenarios}

As noted above, the timing of liberalization has been an important factor in negotiations over China's WTO accession. A central purpose of this paper is to examine one such timing issue. In this paper, the effects of China's accession offer are examined over the period 1995 to 2020 . This time frame is divided into a number of unequal periods: 1995$2000^{2}$, 2000, 2001, 2002, 2003, 2004, 2005, 2006, 2007, 2008, 2009, 2010-2015, 2015-2020. Three simulations are undertaken, one base case simulation and two alternative policy simulations. The base case scenario provides a picture of what we expect the world economy to look like without China's accession to the WTO, while the two policy scenarios are used to examine two alternative timetables for China's accession. The difference between the base case and a given policy simulation shows the effect of China's accession under that particular scenario. We now turn to a detailed discussion of each of these experiments.

\subsection{The Base Case Scenario}

To obtain the base case scenario, forecasts of key macroeconomic variables and any anticipated policy changes are required. Forecasts of the growth rates of gross domestic product, skilled labor, unskilled labor and population for each region were originally obtained from the World Bank (Global Economic Prospects Data Base, 1999), Ahuja and

\footnotetext{
${ }^{2}$ Beginning of 1995 to the beginning of 2000 .
} 
Filmer (1995) and CPB (1999). These were then extrapolated ${ }^{3}$ and adjusted to obtain yearly growth rates for the period 1995 to 2020 . These forecasts were then aggregated to obtain the shocks for the each of the periods and the 19 regions used in the simulation. By way of illustration, the annual growth rates used in the base case scenario for 2005 are provided in Table 1.

The base case scenario also includes some policy shocks which have already occurred, or which are expected to occur, during the period 1995 to 2020. These policy shocks include implementation of the Uruguay Round, including the Agreement on Textiles and Clothing. The UR shocks were calculated from post-UR tariff rates compiled by Francois and Strutt (1999). The reduction in tariffs as a result of the UR and the enlargement of quotas resulting from the ATC are assumed to occur over the period 1995 to 2005 . A number of assumptions are required: firstly, it is assumed that China continues to be granted NTR status under this base case scenario. Therefore tariffs on goods imported from China by WTO members are reduced in line with the UR commitments. Secondly, it is assumed that effective tariffs on agricultural commodities worldwide do not fall further during the 1995-2000 period owing to the fact that UR implementation is not expected to lead to further reductions in agricultural protection. ${ }^{4}$ Thirdly the elimination of quotas on WTO exporters of textiles and clothing under the ATC are incorporated into the simulation as reductions in export tax equivalents obtained from the GTAP database. These export tax equivalents have been reduced gradually over the period 1995 to 2005 to simulate the effects of gradual elimination of the quotas and the associated rents (which are assumed to accrue to exporters). Because these quota liberalization commitments have been heavily back-loaded, the shocks are implemented as follows: only 1 percent of the initial quotas are eliminated in each of the first five years, then 2, 8, 16, 32, 37 percent are eliminated in each of the remaining five years. So that by the year 2000 quotas have been eliminated by 5 percent, 2001 by 7 percent, 2002 by 15 percent and so on. This time path for liberalization of textiles and apparel quotas is shown in Figure 3 (Base Case -- coincides with CHN2005 after 2000).

In addition to the usual UR and ATC shocks, the base case also takes into account some of the trade liberalization undertaken by China prior to the year 2000. China has already made significant progress in reducing tariffs. Failure to include these reforms in the base case scenario could lead to an overestimation of the effects of China's accession ${ }^{5}$. Estimates of these tariff cuts were calculated from 1996 and 1998 tariff rates obtained from Fan and Zheng (2000) ${ }^{6}$.

\footnotetext{
${ }^{3}$ Extrapolation leads to a growth rate for China of approximately 7 percent per year in the years (2007-2020). Maddison (1998) estimates the growth rate between 1995 and 2015 at 4.5 percent per year, suggesting that 7 percent may be an overestimation.

${ }^{4}$ This decision was taken in light of the very high pre-UR tariffs, relative to measured protection in the 1995 database.

${ }^{5}$ Using the dynamic GTAP model it was found that the cumulative difference in real GDP, resulting from China's accession, was approximately 1 percentage point higher if these pre-accession tariff cuts were not taken into account.

${ }^{6}$ The shocks were obtained by calculating the percentage change in tariff rates between 1996 and 1998 rates and then applying these cuts to the GTAP rates in the base case scenario over the period 1995 to 2000.
} 
Technological change in the base case is calibrated using forecasts for real GDP. An initial simulation is undertaken in which all the macro variables, including real GDP, and the policy changes listed above are shocked by the amounts forecasted. In this simulation technology is permitted to respond endogenously to ensure that real GDP tracks the forecast. The resulting values for the technological change variable provide an estimate of how technology is expected to change over the period, if these forecasts for real GDP are to be achieved. Having obtained these values, the base case scenario is again simulated with real GDP determined endogenously and technology exogenously shocked by the value determined in the first simulation. The purpose of this calibration procedure is to ensure that GDP increases as predicted, and to establish a baseline for subsequent comparison with policy scenarios wherein GDP responds to China's WTO accession. The region-specific shocks to technology, which relate to non-accumulable resources, are listed in Table 1. Further details on the base case scenario and the procedures used to obtain these shocks are available in Walmsley, Dimaranan and McDougall (2000).

\subsection{The Policy Scenarios}

In this paper two alternative policy scenarios are examined. Each of these involves implementation of all the shocks from the base case scenario plus the policy simulation. In both policy scenario's China accession is assumed to commence in 2000. The examination of the results, in section 5, will therefore concentrate on the period 2000 to 2020.

1. CHN2005: The first policy scenario involves China being treated as a developed economy. Therefore tariff cuts are expected to be accomplished by the beginning of 2005. ${ }^{7}$ In this scenario, we also assume the quotas on China's textiles and clothing exports to North America and Europe will be removed by the beginning of 2005. Quotas are assumed to be eliminated at a rate of 7, 8, 16, 32 and 37 percent over the five year period 2000 to 2005 (CHN2005 in Figure 3 - overlaps the Base Case from 2000 onwards). This scenario is referred to as CHN2005.

2. SFG2010 In the second scenario, North America and the EU take advantage of safeguards in the original Agreement on textiles and clothing to delay the removal of quotas on Chinese textiles and clothing. Thus quotas are not completely removed until the beginning of 2010. Quotas are assumed to be eliminated at the rate of 1 percent for the first 5 years and then 2, 8, 16, 32, 37 percent each year after that (line labeled SFG2010 in Figure 3). The difference between CHN2005 and SFG2010 is shown in Figure 3 as the difference between the two lines CHN2005 and SFG2010. China is assumed to reduce its tariffs by the beginning of 2005, as in CHN2005. This scenario is referred to as SFG2010. The agreement reached between China and the United States, in November 1999, suggests that it is this scenario that is most likely to occur.

China's accession offer was obtained from Martin et al. (2000) and is based on China's offer as of August, 1999. This offer is compared to their original tariffs for 1997,

\footnotetext{
${ }^{7}$ The reduction in tariffs by China is assumed to occur in equal installments over the period 2000 to 2005 . This is a simplification of the actual accession offer.
} 
and where the binding is lower, the offer is taken as a change in policy. In the case of Taiwan, the cuts are based on their announced target of 4 percent average tariffs for manufactures. Tariffs on agriculture are assumed to be reduced by China in accordance with the accession offer, however no data were available on Taiwan's offer for agriculture and therefore no shocks could be applied. In both scenarios, the reduction in tariffs is assumed to occur in equal installments over the entire period.

\section{Macroeconomic Impacts of China's WTO Accession}

\subsection{Policy Scenario 1: China is treated as a developed country (CHN2005)}

A comprehensive picture of the global impact of China's accession is given in Appendix Table A.2. A selection of these results is reported in the first three columns of Table 2 below. The results report the cumulative differences between the base case and policy scenario at the

beginning of 2020, thus highlighting the long-run effects of China's accession. Here, we trace through the major mechanisms determining the changes in real GDP, capital stocks and welfare. ${ }^{8}$

As a result of China's trade liberalization efforts the price of capital goods in China declines (CHN2005: Figure 4) and capital rentals rise, leading to higher rates of return relative to the base case (CHN2005: Figure 5). Investment and hence capital stocks increase (7.8 percent in Table 2) relative to the base case scenario as a result of the higher rates of return in China, particularly in the first five years following China's accession. Capital

\footnotetext{
${ }^{8}$ One of the benefits of the Dynamic GTAP model is its ability to track foreign ownership and the impact of this foreign ownership on welfare. Determining the overall effect of a policy on welfare and comparing this to the effect on welfare of other policy experiments is a difficult task as welfare results cannot simply be aggregated over time without proper discounting. Furthermore, the results are likely to be highly path dependent since they hinge on the shares or weights given by the initial data base. In a dynamic model the database is updated each period and therefore the shares will depend on the policy shocks (i.e. the path) undertaken. As a result the welfare results of two experiments are not directly comparable, as they have been skewed by the differences in the shares or weights applied. By using a comparative static simulation and the same initial data base (i.e. the 2020 base case data) for both policy experiments, the same weights are now used to calculate the welfare changes and thus the results can be compared directly. We thereby also circumvent the need for discounting a stream of period-by-period welfare measures. In this paper we use a comparative static simulation to show how different welfare would be, with the policy in place, in a particular year -- in this case 2020 . The comparative static simulation is implemented as a single period solution in which capital stocks, expected rates of return, growth rates and foreign ownership, which were previously permitted to accumulate or respond to the policy shock, are now set exogenously and shocked by the cumulative difference between the base case and policy values. In addition the cumulative policy shocks are also implemented. The closure and shocks are set up in such a way that the resulting 2020 database from the comparative static simulation, is the same as the data base obtained from running the policy experiment using the dynamic model. The changes in welfare from the comparative static simulation then indicate how different welfare would be, in 2020, if China's accession were implemented under the two alternative scenarios.
} 
moves into China and Taiwan. The owners of this capital tend to be, first and foremost, the residents of China, followed by investors from competitor economies (columns III and IV in Table A.2), where the rate of return has fallen as a consequence of China's WTO accession. Overall foreign ownership of China's capital increases relative to the base case (CHN2005 in Figure 6) as a result of China's accession.

Figure 7 depicts the cumulative percentage differences from the base case of China's real GDP. The increase in capital stocks gives rise to higher real GDP following China's accession to the WTO. This increases over time, with the cumulative difference reaching 8.6 percent in 2020 (Table 2). From Table 2, we see that China and Taiwan experience the biggest GDP increases following accession. North America, the European Union, Japan and the newly industrialized economies also gain in terms of real GDP. However, in the case of China's competitor economies (e.g., Southeast Asia and South Asia), capital stocks and real GDP fall.

Despite the increased foreign investment, the surge in imports that accompanies China's accession to the WTO requires an increase in exports if China is to remain in balance of payments equilibrium. This increase is exports is accompanied by a decline in average export prices, relative to those of imports and China's terms of trade decline by 3.8 percent (VII in Table A.2) Other countries' terms of trade improve, reflecting the increased demand for their products in China. In Taiwan the terms of trade also improve slightly, suggesting that China's accession has a greater impact on Taiwan's terms of trade than does Taiwan's own liberalization.

Real wages in China increase over the period 2000 to 2010 and then decline. Overall, China's wages for skilled and unskilled workers are higher in 2020 as a consequence of accession (2.4 and 3.1 percent respectively). The increase in competition from China reduces real wages elsewhere, particularly those competing in similar markets to China. In the OECD countries, real wages also decline, although only slightly.

World exports in 2020 are almost 4 percent higher due to China's WTO accession. China leads the way, followed by Taiwan and Japan (V and VI in Table A.2). In North America, both imports and exports increase, however imports, driven by abolition of the textile and apparel quotes, increase by more. Most of this increase in trade occurs over the period 2000 to 2005. China's competitors in the wearing apparel market (India, South Asia and Indonesia) experience an overall decline in exports.

The changes in regional welfare as a consequence of the two accession scenarios are also reported in Table 2. China's large gains stem primarily from improved efficiency. However, the value of China's domestic equity also rises. These gains are partially offset by a decline in her terms of trade (Appendix Table A4). Most other developed and developing economies are better off in terms of welfare as a result of China's accession. Only those directly competing with China in the wearing apparel and labor-intensive manufactures experience a decline in welfare - primarily due to a worsening of their terms of trade. 


\subsection{Scenario 2: North America and Europe employ safeguards to delay ATC implementation (SFG2010)}

In this scenario, still reduces its tariffs over the period 2000 to 2005 . However, North America and the EU prevail in their desire to delay removal of quotas on textiles and wearing apparel, which are not completely eliminated until the beginning of 2010. The results of this scenario are summarized in Table 2. Further details are provided in Appendix Table A.3. Comparison of these results with those obtained in scenario 1 reveals that the gradual reduction of quotas on textiles and clothing over 10 years reduces the gains accruing both to China and to the world as a whole. While real GDP and welfare are lower it is interesting to note that capital accumulation is actually somewhat higher when the elimination of quotas is delayed $(7.9 \%$ as opposed to $7.8 \%)$.

Figure 4 shows the cumulative percentage differences, from base case, of the price of capital goods in China under the two alternative scenarios. It is clear that the price of capital goods falls significantly more when the agreement on textiles and clothing is delayed (SFG2010). These further falls in the price of capital goods are due to an increase in China's production of other manufactures, induced by the continuation of quotas stifling production in China's wearing apparel sector.

As a result of the lower price of capital goods, rates of return under the SFG2010 scenario are almost as high as those obtained when the ATC is not delayed (Figure 5: CHN2005 and SFG2010). Moreover, larger falls in the price of capital goods in later years causes the rate of return to remain higher under the SFG2010 scenario. The higher rate of return on capital in those later years causes investment and capital stocks to continue to increase. Not all of the other economies, however, experience the same fall in price of capital goods as does China under this scenario, hence rates of return and capital stocks do not rise. The reason for this is that capital goods in many of the other developed economies are not as reliant on cheap, labor-intensive manufactures and they are making no further cuts to their own tariffs. China's exports and imports again increase under this policy scenario.

In the case of North America, real GDP and welfare falls slightly (relative to CHN2005) as a result of extending the implementation of the ATC to China (Figure 8). This suggests that North America's attempt to delay the implementation of the ATC is contradictory to maximizing the country's welfare.

Eliminating the quotas on Chinese textiles more slowly does appear to assist China's competitors in terms of Real GDP (e.g., India in Figure 9). However, national welfare in most cases falls further when the ATC is delayed (Table 2). The reduced competition in the wearing apparel sector means that competitors can increase production of wearing apparel (as shown by the increased employment in the wearing apparel sector of India in Figure 12). At the same time however, increased production by China of other manufactures (Figure 13) and electronics (Figure 14) means more competition in these sectors and reduced production by competitors (Figures 15). The long run effect on competitors depends on whether the increase in wearing apparel can offset the decline in other manufactures and electronics. In the case of India and South Asia where wearing apparel accounts for 11 percent of exports 
the delay results in a slightly higher real GDP (Figure 9). In Indonesia and the other South East Asian economies however, other manufactures and electronics are more important and the delay has a much smaller impact on real GDP.

The effect of the delay on foreign ownership of Chinese assets is shown in Figure 6. Foreign ownership increases as a result of China's accession to the WTO, but this increase occurs more gradually when the ATC is delayed. In the long run foreign ownership is greater than if the ATC had not been delayed (CHN2005). Again it is China's own competitors who increase their holdings of assets abroad most. This is due to the decline in their domestic rates of return as a result of China's accession. (We assume there are no restrictions on the flow of capital into China.)

When the agreement on textiles and clothing is delayed the welfare results are lower for China and for the other developed economies, including North America. Surprisingly the welfare results for many of the competitors also worsen (relative to CHN2005), this is due primarily to a further deterioration in the terms of trade. Overall world welfare rises by \$US61334.9 million, when the ATC is delayed world welfare still increases but by only \$US60387 million. 


\section{Sectoral Results}

The whole idea behind the safeguards embodied in the Article VI of the ATC is to prevent "serious damage" to a domestic industry. As can be seen from Figure 12, even in the absence of China's accession to the WTO, employment in wearing apparel in North America is expected to continue its historical decline to only 60 percent of current levels in the base case for 2020. When China enters the ATC this trend is exacerbated so that employment ends up at a mere 33 percent of current levels by the year 2020. This implies substantial adjustments within the sector, and timing becomes key. In particular, how much of this adjustment can be achieved via natural attrition of the work force? Under CHN2005 most of the decline is sustained within the next 5 years - versus 10 years under SFG2010.

In the base case, employment in China's wearing apparel sector is fairly constant. With China's accession to the WTO and the removal of quotas (CHN2005), employment increases sharply during the period 2000-2005 (Figure 10). When the ATC is delayed (SFG2010) the increase in employment in China's wearing apparel sector occurs more gradually, not reaching the same levels as CHN2005 until 2010 (Figure 10).

China's competitors are also affected by the timing of the ATC as applied to China. Consider the case of India. Under the base case, employment is expected to boom in this industry - quadrupling by the time the quotas are eliminated (Figure 12). However with China's accession (CHN2005), growth is more gradual with only half of this increase occurring by 2020. SFG2010 changes this profile considerably, with rapid growth to 2005 , followed by a flattening out and an absolute decline as we approach 2010 and elimination of China's quotas.

These strong swings in textiles and apparel employment have an impact on other sectors as well. In China, the shift from flat growth in employment in the wearing apparel sector to high growth under CHN2005, and medium growth under SFG2010 (Figure 10), draw labor away from other manufacturing activities. Figures 13 and 14 show the impact on other manufactures and electronics employment in China (cumulative percentage differences from base case). CHN2005 has a marked impact on employment. Employment in other manufacturing falls, relative to the base case, during the period 2000 to 2005, increasing again only once the quotas on wearing apparel have been completely removed.

When the elimination of quotas is delayed (SFG2010), production in other manufactures increases. The expansion in the other manufactures sectors, as a result of the delay of ATC implementation, has the effect of increasing competition in these other manufacturing sectors and reducing prices. This reduction in the price of other manufactures is obtained at the expense of the real wages earned by workers in South East Asia, India and Indonesia (VII and IX in Table A.3). In China, other manufactures account for 82 percent of imported inputs and 21 percent of domestic inputs into the capital goods sector. Domestic construction, which also relies on imported manufactured goods, accounts for 65 percent of domestic inputs into the capital goods sector. The combination of the fall in the price of

other manufactures and of construction is the primary reason for the significant fall in the 
price of capital goods in China and sustained increase in capital obtained under the SFG2010 scenario (Figure 4).

In the case of North America and the other developed countries, food and services production and employment tend to increase while manufacturing and in particular wearing apparel employment decline under both scenarios; this is consistent with other studies of China's accession (Wang, 1997a). In India, increased competition in the wearing apparel sector, caused by China's accession, draws resources towards the other labor-intensive manufacturing sectors, such as electronics. Under CHN2005, employment in India's electronics sector increases by 50 percent over the period 2000 to 2005 (Figure 16). When the elimination of quotas on Chinese wearing apparel is delayed however, labor is initially moved into the wearing apparel sector (Figure 13) and the full increase (50\%) in employment in India's electronics sector does not occur until 2010 (Figure 15).

These effects are also reflected in trade flows, with exports by China of wearing apparel increasing significantly, at least 200 percent by 2020 under both scenarios (CHN2005 and SFG2010). This increase in the wearing apparel sector by at least 200 percent is primarily due to the implementation of the ATC on Chinese exports of textiles and clothing to the United States and Europe. However, it is also influenced by the tariff cuts, which make imported intermediate inputs less expensive for exporters of manufactured goods. The latter effect is greatly over-stated in our analysis, since we fail to take account of China's current policy of exempting exporters from many of the tariffs on imported intermediates. Ianchovichina et al. (2000) have recently gathered data on this subject and implemented these duty drawbacks explicitly into a modified version of the GTAP model. They find that the subsequent expansion of wearing apparel exports is much smaller when the drawbacks are taken into consideration. (See also Lejour (2000) on this topic.)

In summary, the sectoral impacts of delaying the ATC are substantial and it is easy to see why the timing of China's accession has received so much political attention. In the case of North America and Western Europe it becomes a question of weighing the higher aggregate benefits from rapid liberalization against the higher sectoral adjustment costs implied by more rapid downsizing of their clothing sectors.

\section{Conclusion}

The timing of trade liberalization has been an important focal point in China's WTO accession negotiations. There has been a great deal of debate over whether China should be treated as a developed or a developing country. In addition, the concerns of North America and Europe over the likely effects of China's accession on their textile and apparel sectors have led them to negotiate in favor of allowing delayed elimination of quotas on these products. This paper explores the latter issue using a dynamic applied general equilibrium model. Two scenarios were considered, both of which assume that China's tariffs will be reduced prior to 2005. In the first scenario, quotas levied by North America and Europe are assumed to be eliminated by the beginning of 2005. In the alternative scenario, North America and Europe take advantage of safeguards to delay the removal of quotas on Chinese textiles and clothing to 2010 . 
We find that the timetable for full implementation of the Agreement on Textiles and Clothing affects the expected benefits of China's accession to the WTO in several important ways. Firstly, consider the impact on China's competitors in the wearing apparel market. India and South East Asia, experience significant falls in real GDP and welfare as a result of China's accession. Surprisingly the fall in welfare is greater when North America and Europe delay the implementation of the ATC, this is due to the affect on welfare of a further deterioration in their terms of trade.

Secondly, the results show that eliminating quotas more gradually, over 10 years, leads to a smaller gain in China's real GDP and welfare than would have occurred if quotas were eliminated according to the official timetable. North America and Europe, the countries responsible for the delay, also experience lower welfare gains as a result of slower implementation. Overall, world welfare in 2020 falls by \$US947 million as a result of this delay.

Finally, insight into the motivation for delayed implementation of the ATC for China may be obtained by examining the sectoral results. Here we see that employment in the North American wearing apparel sector is predicted to be cut by half in the next 20 years in the absence of China's accession. Bringing China into the WTO reduces that projection to about one-third percent of current employment levels in 2020. These job loses are delayed (although not avoided) when the quotas are more gradually phased out. Thus the key question with regard to timing is whether the diminished aggregate welfare gains to the ATC importers are of less value than the more gradual sectoral adjustments. 


\section{References}

Ahuja, V. and D. Filmer. 1995. "Educational Attainment in Developing Countries; New Estimates and projections Disaggregated by Gender," World Bank Policy Research Working Paper 1489, Washington, DC, July.

Anderson, K., B. Dimaranan, T. W. Hertel, and W. Martin, (1997): "Asia-Pacific food markets and trade in 2005: a global, economy-wide perspective", The Australian Journal of Agricultural and Resource Economics, 41(1), pp19-44.

CPB. 1999. "WorldScan: the Core Version," CPB Netherlands Bureau for Economic Policy Analysis, December.

The Economist (2000):"A Survey of China: Now Comes the Hard Part", April $8^{\text {th }}$ to $14^{\text {th }}$, 2000.

Fan, M. and Y. Zheng. (2000): "China's Trade Liberalization for WTO Accession and Its Effects on China - A Computable General Equilibrium Analysis", mimeo.

Francois, J. and A. Strutt. (1999): "Post Uruguay Round Tariff Vectors for GTAP v.4," Memo, June.

Garbaccio, R. F. (1995): "US-China Trade Relations: 1972-95", Paper prepared for the 4th International Symposium on Societies and Economy in East Asia, Oct. 2-3, 1995, Osaka, Japan.

Gelhar, M., (1998): “Time-series Data for Merchandise Trade", in McDougall, R., Elbehri, A., and Troung, T., (eds.) Global Trade, Assistance and Protection: The GTAP 4 Data base, Center for Global Trade Analysis, Purdue University.

Gershman, J., (1999): "U.S. China Relations: Using China as a Proxy: Risks and Errors", Foreign Policy in Focus, http://www.foreignpolicy-infocus.org/papers/china/index.html.

Hertel, T. W. (ed), (1997): Global Trade Analysis: Modeling and Applications. Cambridge: Cambridge University Press.

Ianchovichina, E. I., (1998): "International Capital Linkages: Theory and Applications in A Dynamic Computable General Equilibrium Model," Ph.D. Dissertation, Purdue University.

Ianchovichina, E. I. and R. A. McDougall (2000): Structure of Dynamic GTAP, forthcoming GTAP Technical Paper, Center for Global Trade Analysis, http://www.agecon.purdue.edu/GTAP/techpapr/index.htm.

Ianchovichina, E. I., W. Martin, and E. Fukase (2000): Comparative Study of Trade Liberalisation Regimes: The case of China's Accession to the WTO, paper presented at the Third Annual Conference on Global Trade Analysis, Melbourne, Australia, June 27-30. 
Lejour, A., (2000): China and the WTO: the impact on China and the world economy, paper presented at the Third Annual Conference on Global Trade Analysis, Melbourne, Australia, June 27-30.

Maddison, A., (1998):Chinese Economic Performance in the Long Run, Development Centre Studies, OECD.

Martin, W., B. Dimaranan and T. Hertel, (1999): "Trade Policy, Structural Change and China's Trade Growth", mimeo.

McDougall, R. A., A. Elbehri, T. P. Troung. (ed.), (1998): Global Trade, Assistance and Protection: The GTAP 4 Data Base. Center for Global Trade Analysis, Purdue University.

Scott, R. E. (1999): "China can Wait", EPI Briefing Paper, http://www.epinet.org/briefingpapers /china.html.

USITC (1999): "Assessment of the Economic Effects on the United States of China's Accession to the WTO", U.S. International Trade Commission, Publication 3228, August.

Walmsley, T. L., Dimaranan B. V. and R. A. McDougall (2000): “A Base Case Scenario for the Dynamic GTAP Model”, Center for Global Trade Analysis, Purdue University.

Wang, Z. (1997a): "China and Taiwan access to the World Trade Organization: implications for U.S. agriculture and trade”, Agricultural Economics, 17, 239-264.

Wang, Z. (1997b): "Impact of Cina's WTO Accession on the Labor Intensive exports and Implications for U.S. Agricultural Trade -- A Recursive Dynamic CGE Analysis", Paper presented at the1997 AAEA Meeting, July 28-31, 1997, Toronto, Canada.

Yang, Y., (1996): “China's WTO Membership: What's at Stake?", The World Economy, 19(6), 661-682. 
Figure 1: Foreign Investment in China

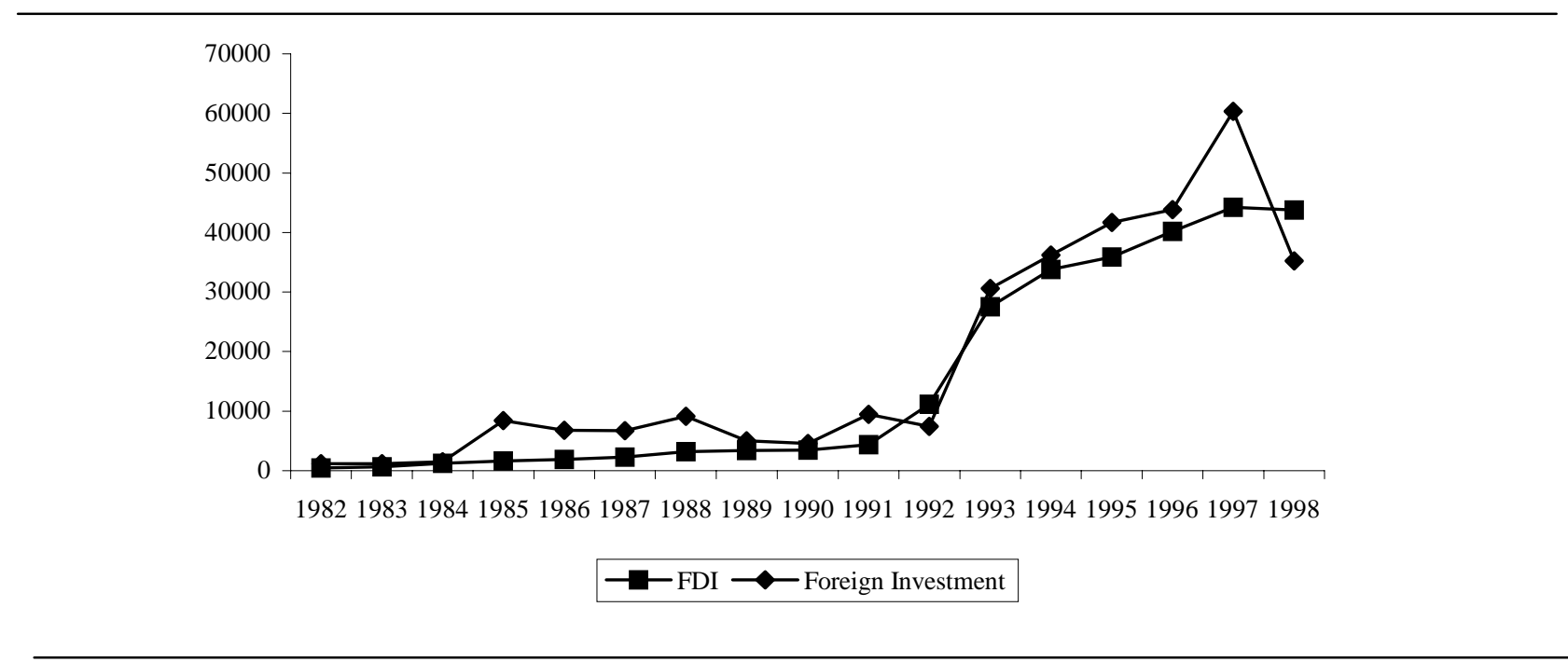

Source: IMF Balance of Payments Statistics, 1999.

Figure 2: Expected and Actual Rate of Return Schedules

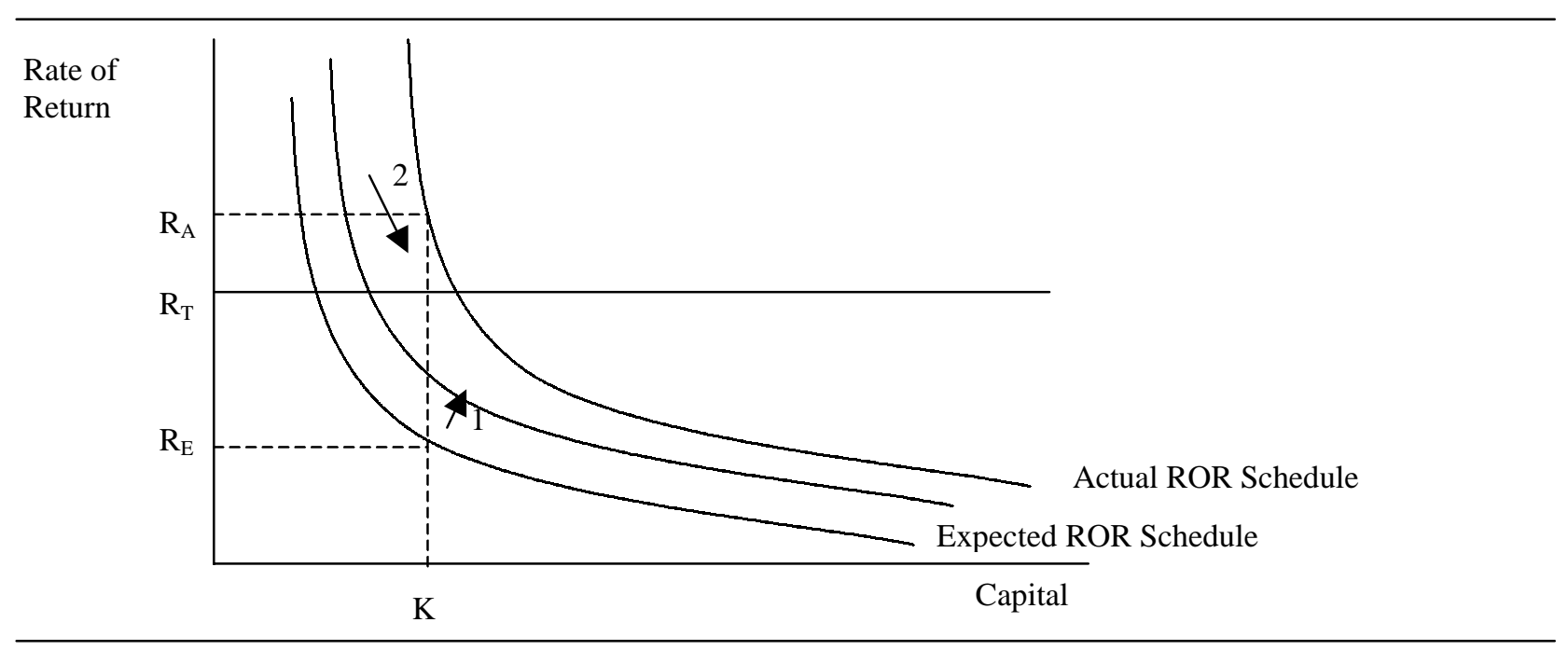

Source: Adapted from Ianchovichina and McDougall (1999) 
Figure 3: Rate at which ATC Quotas are reduced over Time

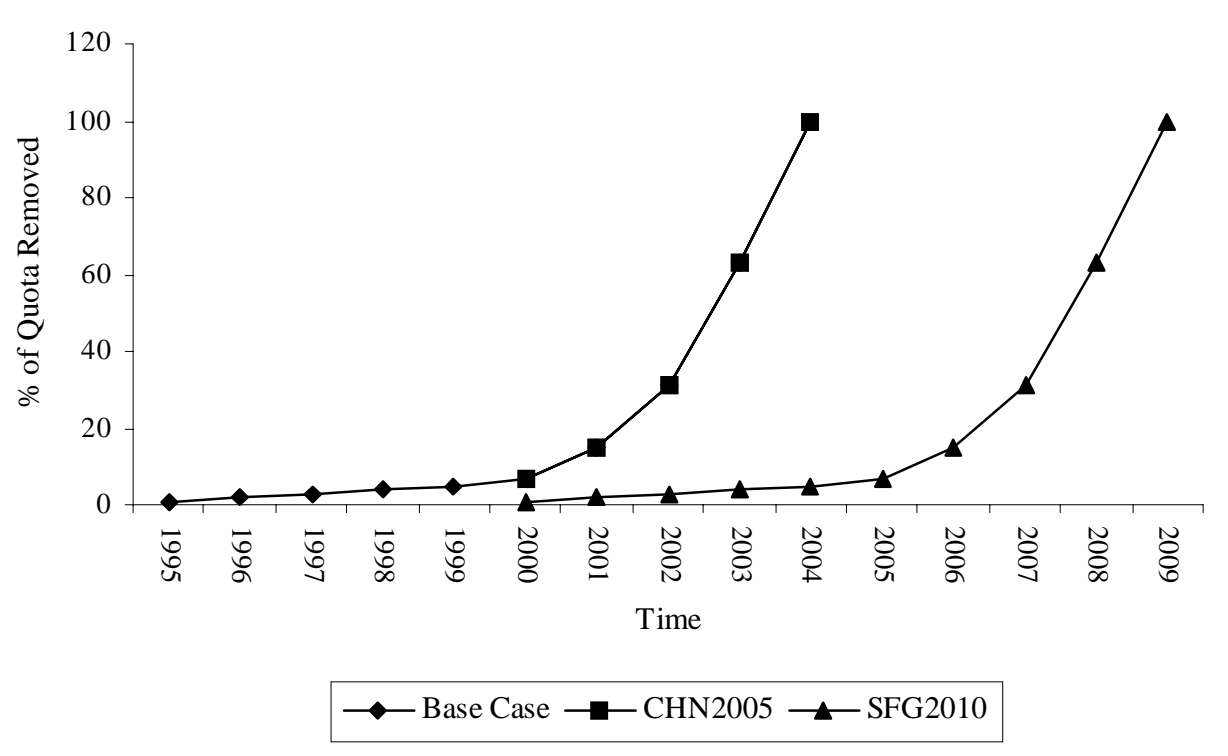

Figure 4: Cumulative Percentage Differences from Base Case in China's Price of Capital Goods

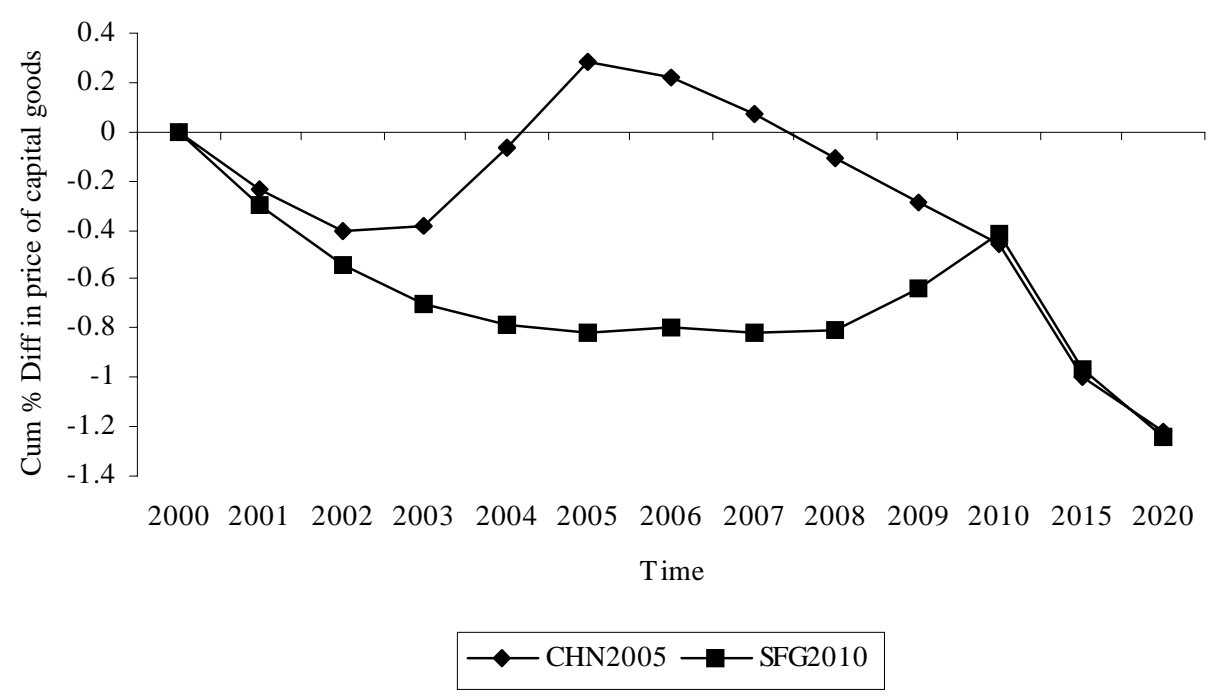


Figure 5: Cumulative Percentage Differences from Base Case in China's Actual Rate of Return

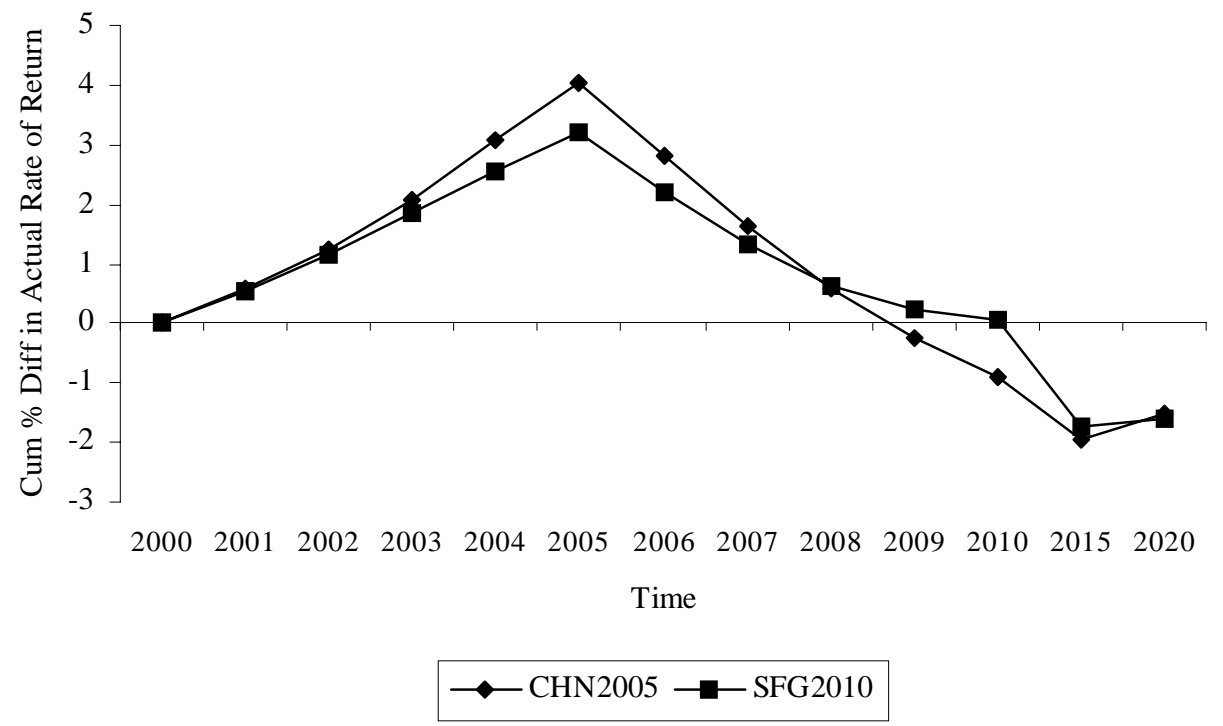

Figure 6: Foreign Ownership of Chinese Assets: Base Case versus CHN2005

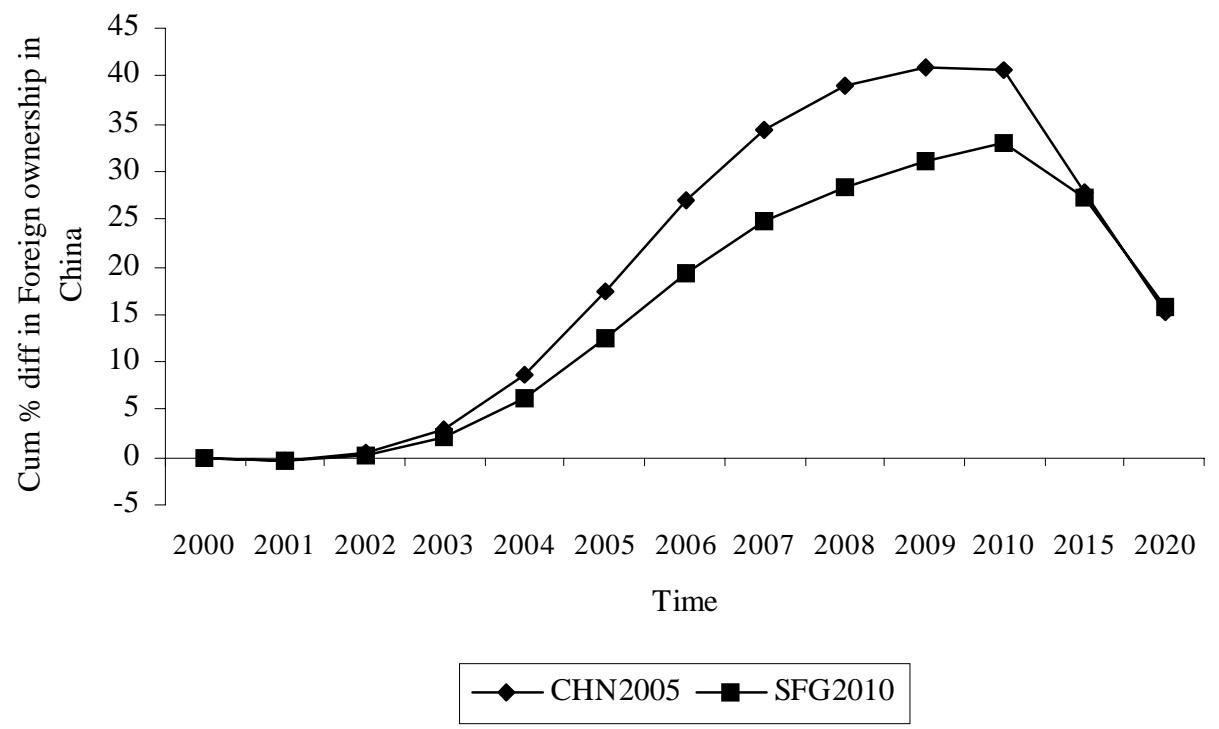


Figure 7: Cumulative Percentage Differences from Base Case in China's Real GDP

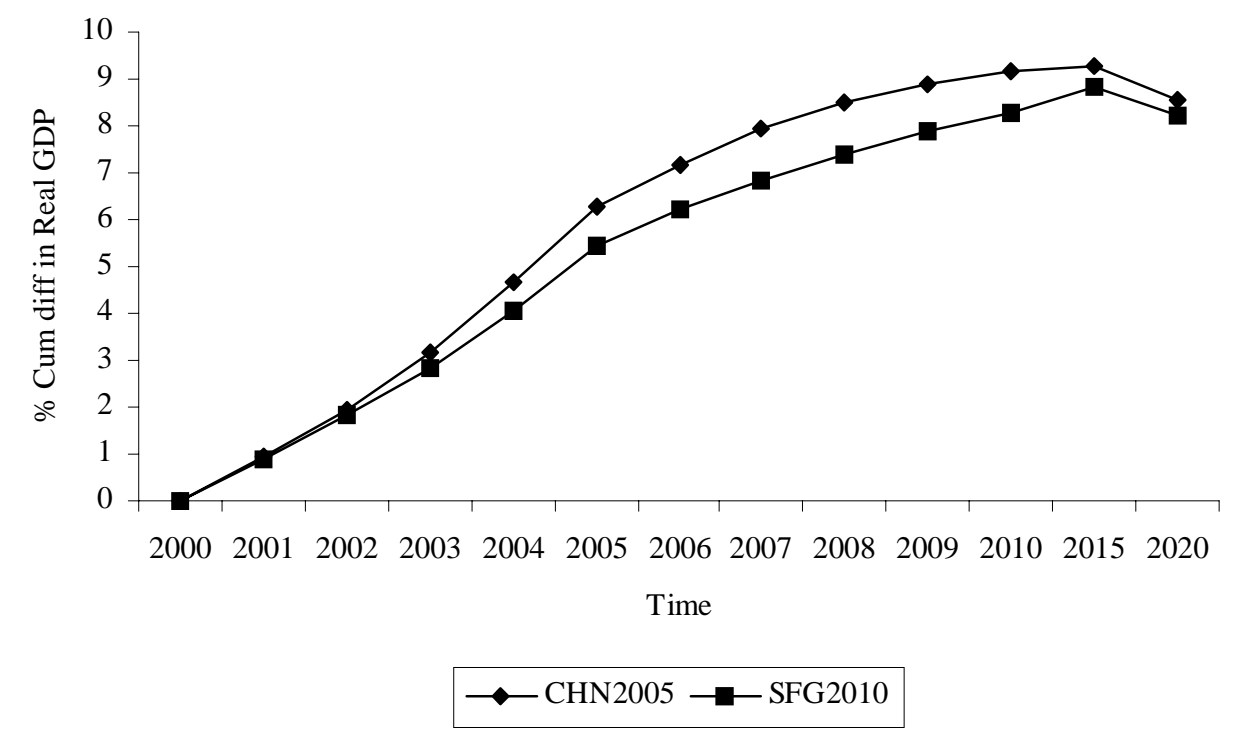

Figure 8: Cumulative Percentage Differences from Base case in North America's Real GDP

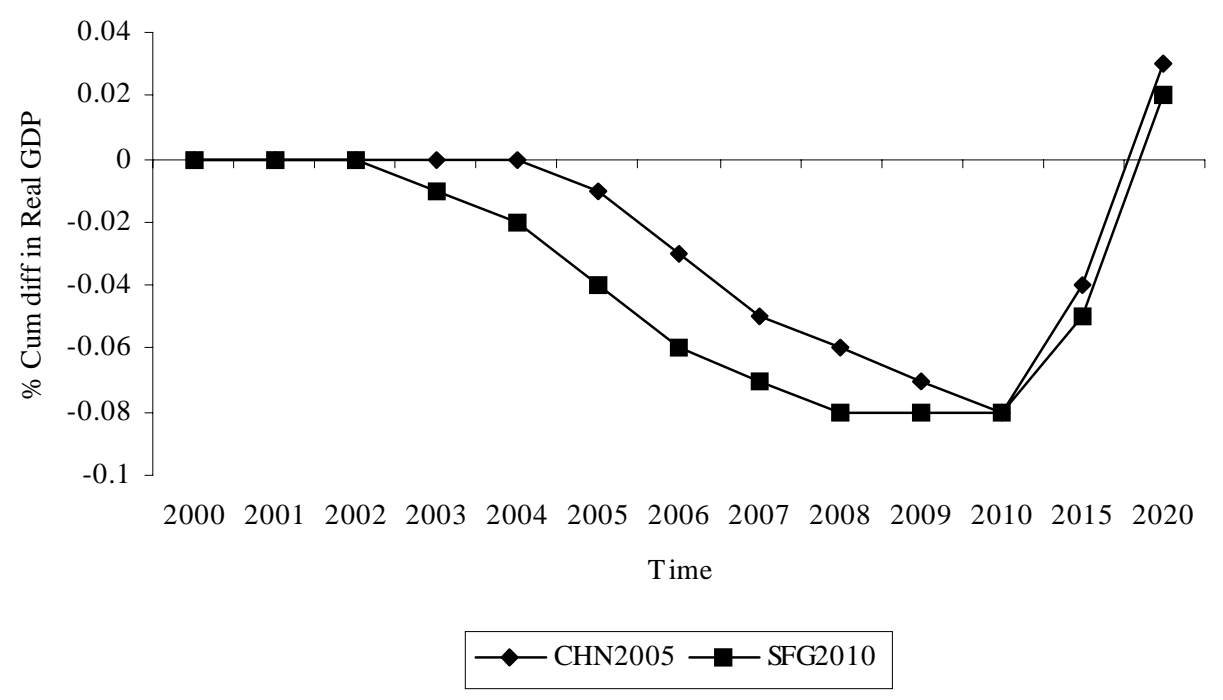


Figure 9: Cumulative Percentage Differences from Base case in India's Real GDP

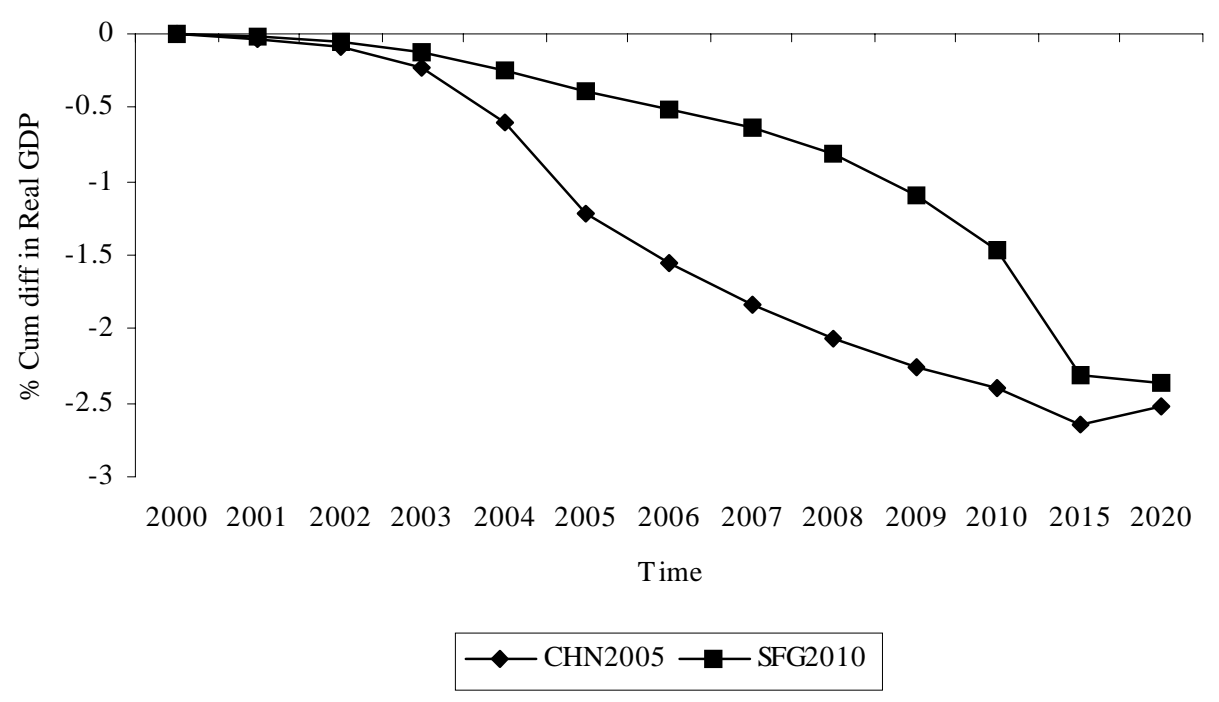

Figure 10: Employment in China's Wearing and Apparel Sector

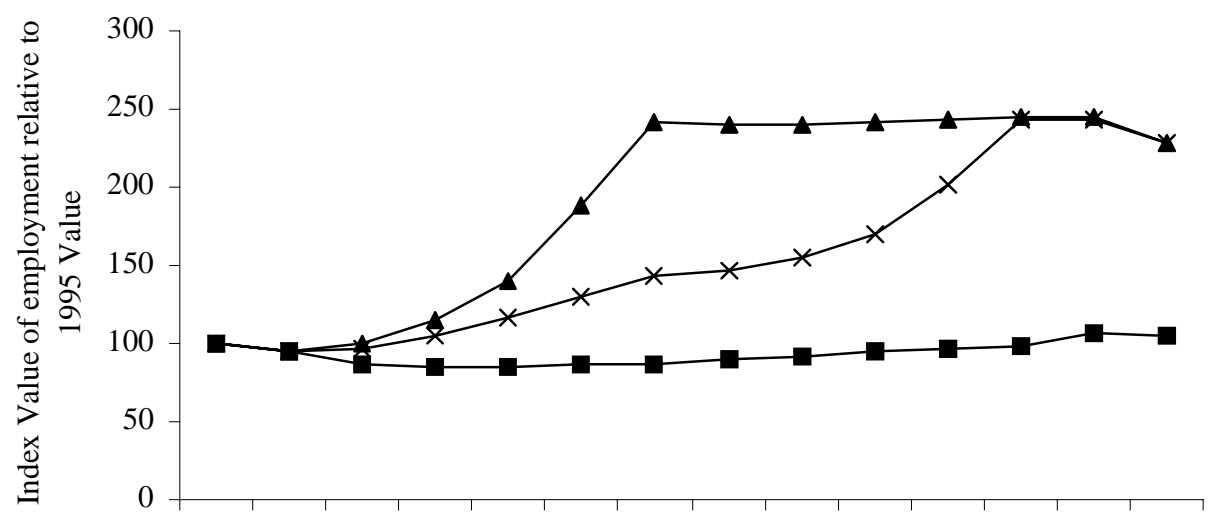

19952000200120022003200420052006200720082009201020152020

Time

$\multimap-$ Base Case $\multimap$ CHN2005 $\leftarrow$ SFG2010 
Figure 11: Employment in North America's Wearing Apparel Sector

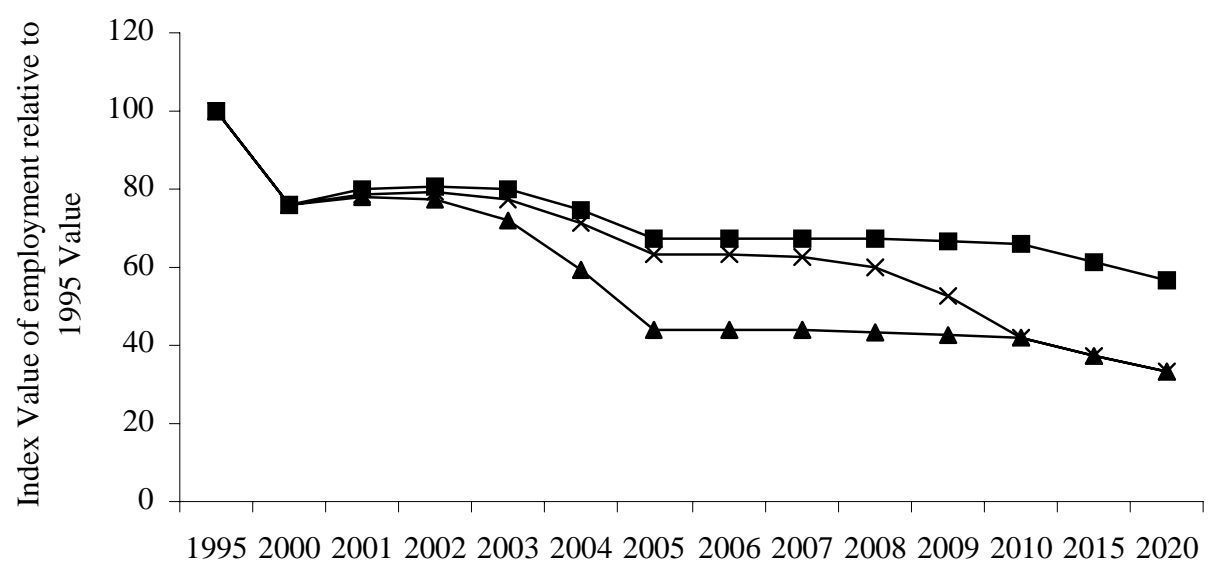

Time

$\longrightarrow$ - Base Case $\multimap$ CHN2005 $\multimap$ SFG2010

Figure 12: Employment in India's Wearing Apparel Sector

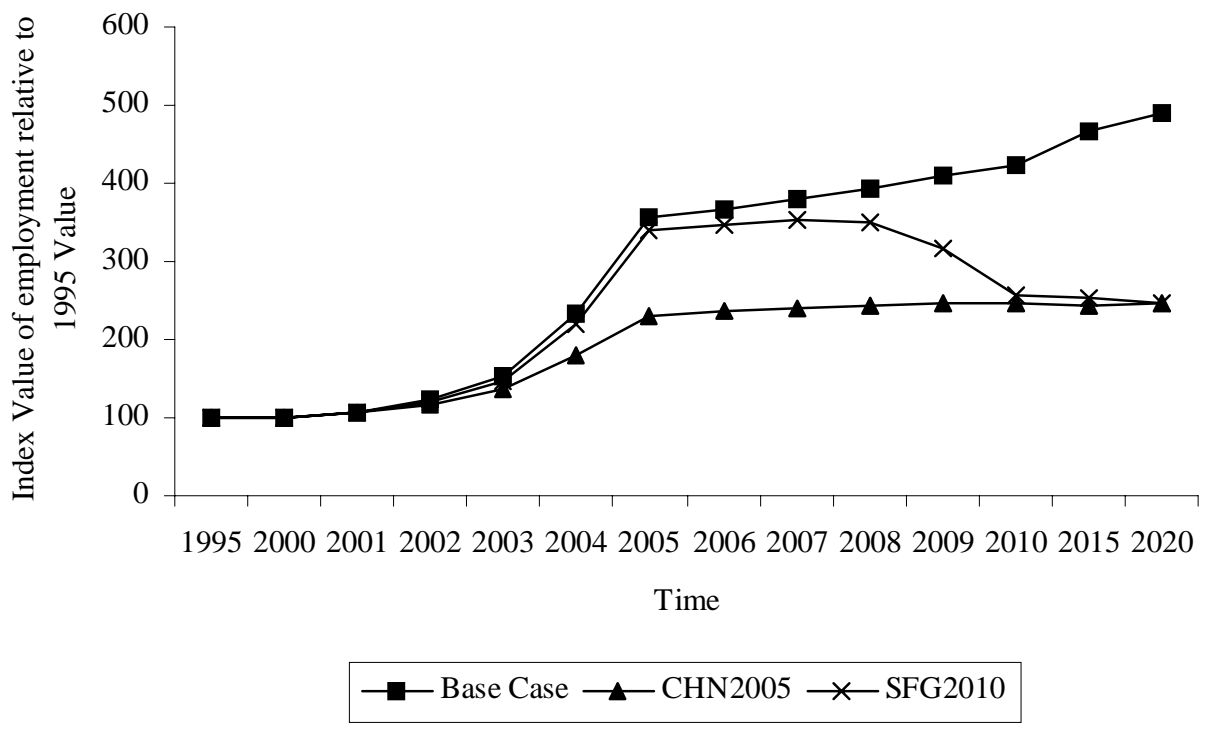


Figure 13: Employment in China's Other Manufactures Sector

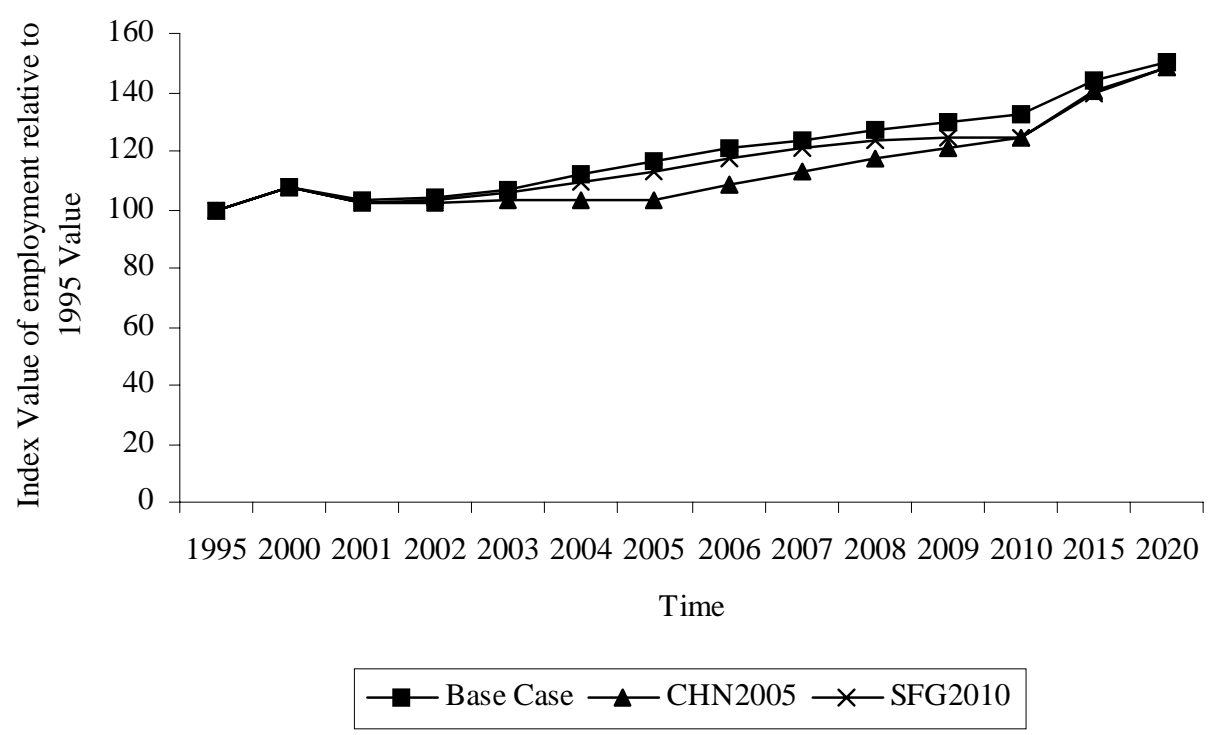

Figure 14: Cumulative Percentage Differences in Employment in China's Electronics Sector

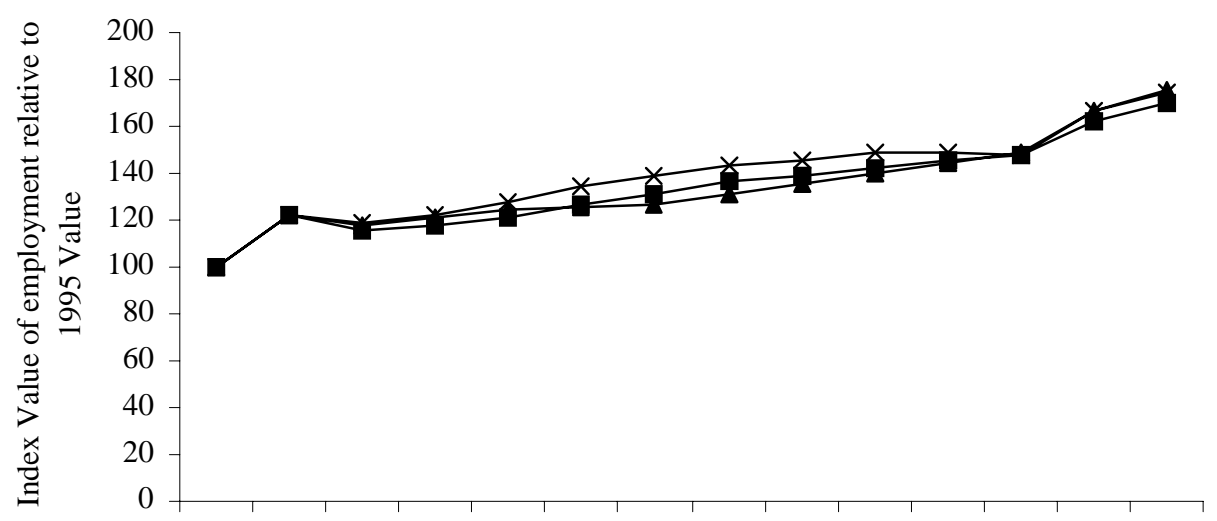

19952000200120022003200420052006200720082009201020152020

Time

$\longrightarrow$ - Base Case $\longrightarrow$ - CHN2005 $\multimap$ SFG2010 
Figure 15: Cumulative Percentage Differences in Employment in India's Electronics Sector

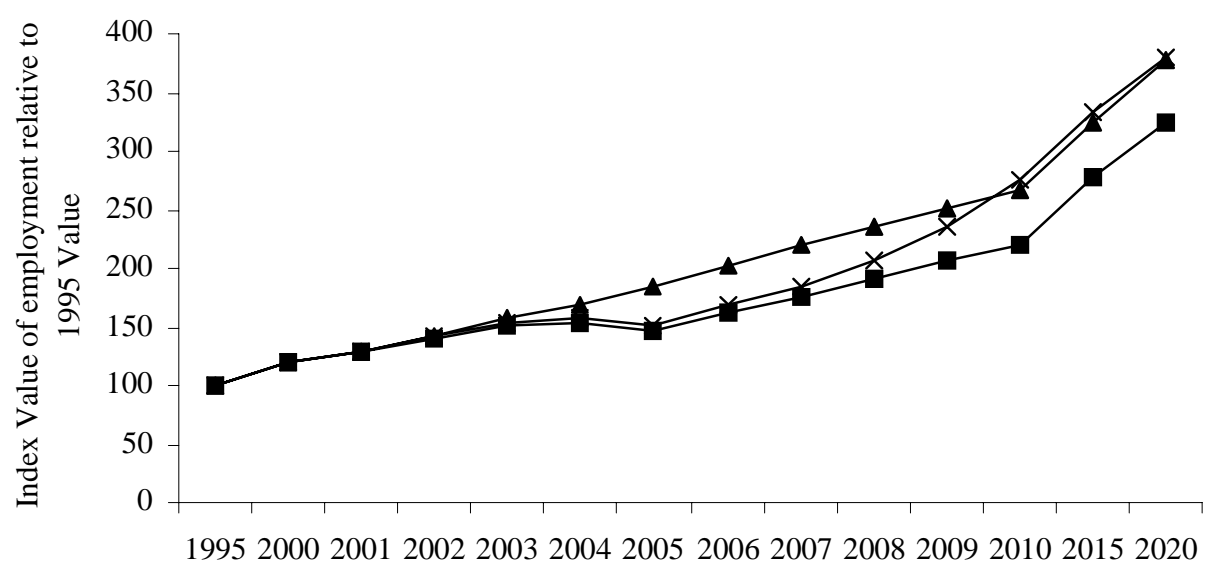

Time

$\longrightarrow$ - Base Case $\longleftarrow$ CHN2005 $¥$ SFG2010 
Table 1 Projected Annual Growth Rates in the Base Line Scenario for the year 2005

\begin{tabular}{|c|c|c|c|c|c|}
\hline & GDP & Unskilled & Skilled & POP & Technology $^{*}$ \\
\hline North America (NAmerica) & 2.6 & 1 & 1.05 & 0.97 & 0.78 \\
\hline Western Europe (WEurope) & 2.61 & -0.21 & -0.01 & -0.03 & 3.07 \\
\hline Australia and New Zealand (AusNZL) & 3.43 & 1.1 & 0.94 & 0.81 & 2.08 \\
\hline Japan & 2.1 & -0.13 & -0.62 & 0.13 & 4.98 \\
\hline China & 7.66 & 1.39 & 3.86 & 0.7 & 6.47 \\
\hline Taiwan & 5.81 & 0.86 & 1.19 & 0.71 & 1.95 \\
\hline Other Newly Industrialized Economies (OthNICs) & 5.57 & -0.54 & 4.29 & 0.65 & 4.39 \\
\hline Indonesia & 5.37 & 1.29 & 7.24 & 1.17 & -0.63 \\
\hline Other South East Asia (OthSEA) & 5.4 & 1.55 & 6.94 & 1.52 & -4.05 \\
\hline India & 5.04 & 1.87 & 5.49 & 1.47 & 2.28 \\
\hline Other South Asia (OthSoAsia) & 5.34 & 2.67 & 5.68 & 1.98 & -0.45 \\
\hline Brazil & 3.49 & 1.54 & 5.46 & 1.2 & 1.08 \\
\hline Other Latin America (OthLatAm) & 4.43 & 0.73 & 5.87 & 1.51 & 1.86 \\
\hline Turkey & 5.02 & 1.8 & 7.22 & 1.27 & -1.49 \\
\hline Other Middle East and Northern Africa OthMENA) & 3.96 & 3.13 & 5.23 & 2.34 & 0.56 \\
\hline Economies in Transition (EIT) & 4.89 & 0.53 & 0.92 & 0.41 & 5.23 \\
\hline Southern Africa Customs Union (SoAfrCU) & 3.68 & 2.49 & 2.91 & 2.01 & 1.36 \\
\hline Other Sub-Saharan Africa (OthSSA) & 4.28 & 3.16 & 3.76 & 2.71 & 1.35 \\
\hline Rest of World (ROW) & 4.12 & 1.96 & 3.02 & 1.36 & 0.53 \\
\hline
\end{tabular}

This reflects productivity growth for labor, land and natural resources. 
Table 2. Results for China's WTO Accession Cumulative Percentage Change in 2020

\begin{tabular}{lcccccc}
\hline & \multicolumn{3}{c}{ CHN2005 } & \multicolumn{3}{c}{ SFG2010 } \\
\hline NAmerica & 0.03 & 0.03 & 11281.72 & 0.02 & 0 & 11134.05 \\
WEurope & 0.15 & 0.42 & 13194.35 & 0.14 & 0.39 & 13129.62 \\
AusNZL & 0.26 & 0.67 & 2278.326 & 0.26 & 0.66 & 2267.771 \\
Japan & 0.29 & 0.59 & 6272.554 & 0.27 & 0.55 & 5897.416 \\
China & 8.58 & 7.82 & 27148.78 & 8.25 & 7.91 & 27054.66 \\
Taiwan & 4.39 & 9.1 & 3989.531 & 4.37 & 9.1 & 3990.354 \\
OthNICs & 0.62 & 1.44 & 2439.614 & 0.66 & 1.42 & 2486.147 \\
Indonesia & -1.61 & -2.75 & -569.561 & -1.57 & -2.73 & -573.238 \\
OthSEA & -1.75 & -2.5 & -3002.42 & -1.76 & -2.5 & -2974.66 \\
India & -2.53 & -5.65 & -4126.21 & -2.37 & -5.91 & -4214.81 \\
OthSoAsia & -3.37 & -6.83 & -2349.65 & -3.17 & -6.84 & -2444.55 \\
Brazil & -0.25 & -0.48 & -525.684 & -0.26 & -0.49 & -535.04 \\
OthLatAm & -1.19 & -2.27 & -1774.9 & -1.18 & -2.29 & -1910.48 \\
Turkey & -3.23 & -5.04 & -3174.95 & -3.11 & -4.88 & -3098.62 \\
OthMENA & 0.16 & 0.56 & 6508.416 & 0.16 & 0.54 & 6487.03 \\
EIT & -0.04 & -0.19 & 3411.007 & -0.04 & -0.2 & 3397.113 \\
SoAfrCU & 0.22 & 0.73 & 748.1247 & 0.21 & 0.69 & 742.9333 \\
OthSSA & -0.22 & -0.02 & 1249.4 & -0.22 & -0.07 & 1231.574 \\
ROW & -1.48 & -2.8 & -1663.53 & -1.45 & -2.77 & -1679.68 \\
World & & & 61334.9 & & & 60387.6 \\
\hline
\end{tabular}




\section{Appendix}

Table A.1: List of Countries and Commodities of the Study

\begin{tabular}{|c|c|c|c|}
\hline \multicolumn{2}{|c|}{ Country/Region } & \multicolumn{2}{|l|}{ Commodity } \\
\hline NAmerica & North America & foodgrains & Rice and wheat \\
\hline WEurope & Western Europe & feedgrains & Coarse grains \\
\hline AusNZL & Australia and New Zealand & Oilseeds & oilseeds \\
\hline Japan & Japan & Meatlstk & Ruminants and non-ruminants animals \\
\hline China & China & Dairy & Dairy \\
\hline Taiwan & Taiwan & Othagr & Other farm products \\
\hline OthNICs & $\begin{array}{l}\text { Other Newly Industrializing } \\
\text { Countries }\end{array}$ & othfood & Other processed foods \\
\hline Indonesia & Indonesia & bevtobac & Beverages and tobacco \\
\hline OthSEA & Other South East Asia & Extract & Mining, fish, forestry \\
\hline India & India & Textiles & Textiles \\
\hline OthSoAsia & Other South Asia & wearapp & Wearing apparel \\
\hline Brazil & Brazil & woodpaper & Wood and paper products \\
\hline OthLatAm & Other Latin America & pchemineral & $\begin{array}{l}\text { petroleum, coal, chemicals, rubbers } \\
\text { and plastics, non-metalic mineral } \\
\text { products }\end{array}$ \\
\hline Turkey & Turkey & Metals & Metals and metal products \\
\hline OthMENA & $\begin{array}{l}\text { Other Middle East and North } \\
\text { Africa }\end{array}$ & Autos & Motor vehicles and parts \\
\hline EIT & Economies in Transition & electronics & Electronic equipment \\
\hline SoAfrCU & South African Customs Union & othmnfcs & Other trans equipment and machinery \\
\hline OthSSA & Other Sub-Saharan Africa & houseutils & Housing and utilities \\
\hline \multirow[t]{4}{*}{ ROW } & Rest of World & tradetrans & Trade and transport services \\
\hline & & construction & Construction services \\
\hline & & busfinance & Business and financial services \\
\hline & & govservice & Government services \\
\hline
\end{tabular}


Table A.2 Tariffs and Quotas Abolished by 2005 - Cumulative Percentage Change in 2020 due to CHN2005 ${ }^{1}$.

\begin{tabular}{|c|c|c|c|c|c|c|c|c|c|c|}
\hline & \multirow[b]{2}{*}{ I } & \multirow[b]{2}{*}{ II } & \multirow[b]{2}{*}{ III } & \multirow{2}{*}{$\begin{array}{l}\text { Wealth } \\
\text { IV }\end{array}$} & \multicolumn{2}{|c|}{ Trade } & \multicolumn{4}{|c|}{ Real Wages } \\
\hline & & & & & $\mathrm{V}$ & VI & VII & VIII & IX & $X$ \\
\hline & Real GDP & $\begin{array}{l}\text { Capital } \\
\text { Stocks }\end{array}$ & $\begin{array}{c}\text { Wealth in } \\
\text { Domestic } \\
\text { Assets }\end{array}$ & $\begin{array}{c}\text { Wealth in } \\
\text { Foreign } \\
\text { Assets }\end{array}$ & Exports & Imports & $\begin{array}{c}\text { Terms of } \\
\text { Trade }\end{array}$ & Skilled Labor & $\begin{array}{l}\text { Unskilled } \\
\text { Labor }\end{array}$ & $\begin{array}{c}\text { Welfare } \\
\text { (US \$million) }\end{array}$ \\
\hline NAmerica & 0.03 & 0.03 & -0.03 & -0.14 & 0.7 & 1.75 & 0.31 & -0.23 & -0.32 & 11281.72 \\
\hline WEurope & 0.15 & 0.42 & 0.53 & -0.02 & 1.44 & 1.52 & 0.4 & -0.11 & -0.15 & 13194.35 \\
\hline AusNZL & 0.26 & 0.67 & 0.59 & -0.59 & 1.65 & 1.99 & 1.12 & -0.34 & -0.46 & 2278.326 \\
\hline Japan & 0.29 & 0.59 & 1.12 & -0.27 & 6.43 & 4.95 & 0.35 & -0.01 & -0.06 & 6272.554 \\
\hline China & 8.58 & 7.82 & 6.48 & -1.49 & 35.23 & 39.4 & -3.81 & 2.41 & 3.11 & 27148.78 \\
\hline Taiwan & 4.39 & 9.1 & 5.79 & -14.05 & 17 & 16.31 & 0.18 & 2.06 & 3.48 & 3989.531 \\
\hline OthNICs & 0.62 & 1.44 & 1.36 & -4.11 & 3.92 & 3.97 & 0.46 & 0.18 & 0.56 & 2439.614 \\
\hline Indonesia & -1.61 & -2.75 & 0.39 & 12.74 & -1.54 & -0.83 & 0.48 & -2.44 & -2.5 & -569.561 \\
\hline OthSEA & -1.75 & -2.5 & -0.22 & 6.28 & -1.17 & -1.11 & -0.14 & -1.82 & -2.26 & -3002.42 \\
\hline India & -2.53 & -5.65 & -5.72 & 163.03 & -6.86 & -5.08 & -0.13 & -1.82 & -3.55 & -4126.21 \\
\hline OthSoAsia & -3.37 & -6.83 & -1.34 & 7.46 & -6.96 & -6.1 & -1.11 & -1.48 & -3.32 & -2349.65 \\
\hline Brazil & -0.25 & -0.48 & 0.24 & 1.07 & -0.88 & 1.34 & -0.34 & -0.45 & -0.59 & -525.684 \\
\hline OthLatAm & -1.19 & -2.27 & 0.16 & 3.32 & -2.52 & -1.06 & -0.31 & -1.29 & -1.83 & -1774.9 \\
\hline Turkey & -3.23 & -5.04 & -0.93 & 7.86 & -5.24 & -5.82 & -1.11 & -2.56 & -3.45 & -3174.95 \\
\hline OthMENA & 0.16 & 0.56 & 0.74 & -0.29 & 2.12 & 1.9 & 2.09 & -1.02 & -1.46 & 6508.416 \\
\hline EIT & -0.04 & -0.19 & 0.48 & 1.71 & 1.25 & 1.47 & 0.94 & -0.82 & -1.13 & 3411.007 \\
\hline SoAfrCU & 0.22 & 0.73 & 0.53 & -0.94 & 2.04 & 2.62 & 1.32 & -0.34 & -0.57 & 748.1247 \\
\hline OthSSA & -0.22 & -0.02 & 0.22 & 0.29 & 1.01 & 1.02 & 1.92 & -1.23 & -1.51 & 1249.4 \\
\hline ROW & -1.48 & -2.8 & -0.2 & 3.49 & -1.89 & -1.39 & -0.98 & -1.58 & -2.36 & -1663.53 \\
\hline
\end{tabular}

\footnotetext{
${ }^{1}$ Simulation CHN2005: Tariff reductions and ATC implemented over the period 2001 to 2005. Cumulative differences between Base Case and Policy Shock at the beginning of 2020 .
} 
Table A.3 Tariffs Abolished by 2005, Quotas Abolished by 2010 - Cumulative Percentage Change in 2020 due to SFG2010².

\begin{tabular}{|c|c|c|c|c|c|c|c|c|c|c|}
\hline & & & & Wealth & & & & $\overline{\text { Real Wa }}$ & & \\
\hline & I & II & III & IV & $\mathrm{V}$ & VI & VII & VIII & IX & $\mathrm{X}$ \\
\hline & Real GDP & $\begin{array}{l}\text { Capital } \\
\text { Stocks }\end{array}$ & $\begin{array}{c}\text { Wealth in } \\
\text { Domestic } \\
\text { Assets }\end{array}$ & $\begin{array}{c}\text { Wealth in } \\
\text { Foreign } \\
\text { Assets }\end{array}$ & Exports & Imports & $\begin{array}{c}\text { Terms of } \\
\text { Trade }\end{array}$ & Skilled Labor & $\begin{array}{l}\text { Unskilled } \\
\text { Labor }\end{array}$ & $\begin{array}{c}\text { Welfare } \\
\text { (US \$million) }\end{array}$ \\
\hline NAmerica & 0.02 & 0 & -0.06 & -0.08 & 0.64 & 1.71 & 0.29 & -0.23 & -0.33 & 11134.05 \\
\hline WEurope & 0.14 & 0.39 & 0.47 & -0.05 & 1.39 & 1.49 & 0.4 & -0.12 & -0.16 & 13129.62 \\
\hline AusNZL & 0.26 & 0.66 & 0.56 & -0.58 & 1.59 & 1.98 & 1.12 & -0.34 & -0.46 & 2267.771 \\
\hline Japan & 0.27 & 0.55 & 1.06 & -0.32 & 6.32 & 4.95 & 0.39 & -0.02 & -0.07 & 5897.416 \\
\hline China & 8.25 & 7.91 & 6.54 & -2.04 & 35.12 & 39.48 & -3.37 & 2.36 & 3.07 & 27054.66 \\
\hline Taiwan & 4.37 & 9.1 & 5.74 & -14.22 & 16.88 & 16.38 & 0.21 & 2.01 & 3.45 & 3990.354 \\
\hline OthNICs & 0.66 & 1.42 & 1.33 & -4.01 & 3.85 & 3.94 & 0.42 & 0.16 & 0.54 & 2486.147 \\
\hline Indonesia & -1.57 & -2.73 & 0.36 & 12.71 & -1.42 & -0.89 & 0.42 & -2.39 & -2.46 & -573.238 \\
\hline OthSEA & -1.76 & -2.5 & -0.23 & 6.36 & -1.2 & -1.14 & -0.15 & -1.82 & -2.27 & -2974.66 \\
\hline India & -2.37 & -5.91 & -6 & 181.54 & -6.74 & -5.44 & -0.97 & -1.77 & -3.55 & -4214.81 \\
\hline OthSoAsia & -3.17 & -6.84 & -1.31 & 7.65 & -6.6 & -6.51 & -1.35 & -1.27 & -3.16 & -2444.55 \\
\hline Brazil & -0.26 & -0.49 & 0.2 & 1.05 & -0.92 & 1.29 & -0.33 & -0.46 & -0.59 & -535.04 \\
\hline OthLatAm & -1.18 & -2.29 & 0.1 & 3.33 & -2.19 & -1.33 & -0.36 & -1.23 & -1.82 & -1910.48 \\
\hline Turkey & -3.11 & -4.88 & -0.94 & 7.63 & -4.94 & -5.85 & -1.09 & -2.48 & -3.38 & -3098.62 \\
\hline OthMENA & 0.16 & 0.54 & 0.71 & -0.27 & 2.06 & 1.9 & 2.07 & -1 & -1.44 & 6487.03 \\
\hline EIT & -0.04 & -0.2 & 0.44 & 1.73 & 1.21 & 1.43 & 0.93 & -0.82 & -1.12 & 3397.113 \\
\hline SoAfrCU & 0.21 & 0.69 & 0.5 & -0.87 & 1.98 & 2.58 & 1.31 & -0.35 & -0.57 & 742.9333 \\
\hline OthSSA & -0.22 & -0.07 & 0.19 & 0.33 & 0.95 & 0.99 & 1.87 & -1.23 & -1.51 & 1231.574 \\
\hline ROW & -1.45 & -2.77 & -0.26 & 3.37 & -1.71 & -1.47 & -0.99 & -1.54 & -2.33 & -1679.68 \\
\hline
\end{tabular}

\footnotetext{
${ }^{2}$ Simulation SFG2010: Tariff reductions implemented over the period 2000 to 2004. ATC implemented over the period 2000 to 2009. Cumulative differences between Base Case and Policy Shock at the beginning of 2020.
} 
Appendix Table A4. Decomposition of the Change in China's Welfare in 2020

\begin{tabular}{lll}
\hline & CHN2005 & SFG2010 \\
\hline Total Welfare & 27148.78 & 27054.66 \\
Allocative Efficiency & $113.36 \%$ & $114.27 \%$ \\
Equity & $24.99 \%$ & $24.18 \%$ \\
Terms of Trade & $-34.25 \%$ & $-34.36 \%$ \\
Technology & $0.00 \%$ & $0.00 \%$ \\
Non-accumulable Endowments & $0.00 \%$ & $0.00 \%$ \\
Adjustment for non-homotheticity & $-4.09 \%$ & $-4.09 \%$ \\
\hline
\end{tabular}

